\title{
35. CHARACTERIZATION OF INSOLUBLE ORGANIC MATTER IN SEDIMENTS FROM THE NANKAI TROUGH, DEEP SEA DRILLING PROJECT LEG 87A ${ }^{1}$
}

\author{
Tsutomu Machihara, Technology Research Center, Japan National Oil Corporation ${ }^{2}$
}

\begin{abstract}
Lipids, humic acids, and kerogens were isolated from Site 582 sediment cores. The amount of each organic fraction in the samples taken from 5.6 to $694 \mathrm{~m}$ sub-bottom is almost unrelated to depth of the sample. A study of the oxidation of organic matter by the alkaline $\mathrm{KMnO}_{4}$ method reveals that distribution of polymethylene chain lengths of the kerogens and humic acids in the marine sediments differ from those in lacustrine sediments. The order of abundance of these chains in the sediments is: kerogens, $52-66 \%$ of total methylene chains; humic acids, $25-33 \%$; and lipids, $8-16 \%$. The results suggest that polyunsaturated fatty acids ( $\geq 4$ double bonds) may be important in the formation of polymethylene chains of kerogens and humic acids in marine sediments.
\end{abstract}

\section{INTRODUCTION}

Insoluble organic matter (kerogen) constitutes a major portion of all organic matter in sediments. Many degradation studies, such as oxidation studies (Philp and Yang, 1977; Machihara and Ishiwatari, 1981) and pyrolysis studies (Philp et al., 1978; Sklarew, 1979), have shown the presence of polymethylene chains $\left(-\left(\mathrm{CH}_{2}\right)_{\mathrm{n}}-\right)$ in the kerogen structure. However, precursors and the formation process of polymethylene chains in kerogen are not well known. The study of the chemical structure and the source of the polymethylene chains in kerogens is important, because thermal degradation may transform these chains into aliphatic petroleum hydrocarbons (Welte, 1972; Tissot and Welte, 1978; Hunt, 1979).

In a previous report (Ishiwatari and Machihara, 1983), we examined lipids, humic acid, and kerogen in lacustrine sediment by the $\mathrm{KMnO}_{4}$ oxidation method. Those results demonstrate that the molecular distribution of polymethylene chains (normal aliphatic $\alpha, \omega$-dicarboxylic acids as major degradation products) are similar among the three fractions. This similarity indicates a common origin for the polymethylene chains of these three organic materials.

We report on the study of oxidation of three organic fractions (lipids, humic acid, and kerogen) from Site 582 samples, in order to compare the characteristics of these three organic materials from a marine sediment in terms of their polymethylene chains. Humic acid was included in this study, because some marine sediments contain these acids in relatively large amounts (Degens et al., 1964; Stuermer et al., 1978; Sato, 1980).

\section{METHODS}

\section{Sample Description}

Sediment samples used in this study are muds (Cores 582-1 and 582B-3 to 582B-50) or mudstones (Cores 582B-58 and 582B-68) of

\footnotetext{
${ }^{1}$ Kagami, H., Karig, D. E., Coulbourn, W. T., et al., Init. Repts, DSDP, 87: Washington U.S.S. Govt. Printing Office).

2 Address: Technology Research Center, Japan National Oil Corporation, 3-5-5, Midorigaoka, Hamura-cho, Nishitama-gun, Tokyo, 190-11 Japan.
}

Quaternary age (Table 1). Age at the base of Hole 582B $(749.4 \mathrm{~m})$ is approximately $0.65 \mathrm{Ma}$ (Kagami et al., 1983).

Separation of Lipids, Humic Acid, and Kerogen

A freeze-dried sediment sample $(50-67 \mathrm{~g})$ was ground to a fine powder and extracted with benzene-methanol (6:4) in a Soxhlet apparatus for $70 \mathrm{hr}$. to remove lipids. Sulfur was removed by adding copper to the boiling solution. A portion (approximately $30 \mathrm{~g}$ ) of the sediment residue was subsequently extracted with a solution of $0.5 \mathrm{~N}$ $\mathrm{NaOH}(50 \mathrm{ml} \times 5)$ by ultrasonication $(20 \mathrm{kHz} ; 60$ minutes $\times 3)$ at approximately $50^{\circ} \mathrm{C}$ to remove humic and fulvic acids. The alkaline solution was filtered through a Whatman GF/C filter, acidified with $6 \mathrm{~N}$ $\mathrm{HCl}$ to a pH of approximately 1 and centrifuged to obtain the humic acid. This acid was purified by dissolution in a $0.2 \mathrm{~N}$ solution of $\mathrm{NaOH}$, filtered through a GF/C filter, acidified to a $\mathrm{pH}$ of approximately 1 , and centrifuged. The resulting humic acid was rinsed with distilled water and freeze-dried. The residue from the alkaline extraction was treated with $46 \% \mathrm{HF} / 6 \mathrm{~N} \mathrm{HCl}(1: 1)$ solution to decompose inorganic materials. The kerogen was concentrated from the inorganics by using heavy liquid $\left(\mathrm{ZnCl}_{2}\right.$ at specific gravity 2.0$)$. The kerogen thus obtained was washed with distilled water and freeze-dried. Because the ash content of the kerogen was high $(60-70 \%)$, it was further treated with $6 \mathrm{~N} \mathrm{HCl}$ at $95^{\circ} \mathrm{C}$ for $10 \mathrm{hr}$. in order to decrease inorganic materials.

\section{Alkaline Potassium Permanganate Oxidation}

The methods of oxidation and extraction of degradation products are reported in detail elsewhere (see Machihara and Ishiwatari, 1983). Briefly, a sample $(2-20 \mathrm{mg})$ of lipids, humic acid, or kerogen was mixed with $10 \mathrm{ml}$ of $2 \% \mathrm{KMnO}_{4}$ in $1 \% \mathrm{KOH}$ aqueous solution and allowed to react for 60 minutes at $60^{\circ} \mathrm{C}$. The degradation products were extracted, silylated, and analyzed by gas chromatography (GC) or gas chromatography-mass spectrometry (GC-MS).

\section{Instrumentation}

GC analyses were carried out on a Hewlett-Packard 5840A gas chromatograph with a flame ionization detector. GC separations were performed using a Hewlett-Packard OV-1 fused silica capillary column ( $25 \mathrm{~m}$ long $\times 0.31 \mathrm{~mm}$ internal diameter). The column temperature was programmed from $90-280^{\circ} \mathrm{C}$ at $10^{\circ} \mathrm{C} /$ minute.

Degradation products were quantified by measuring their peak heights or peak areas on the gas chromatograms. Standards are normal saturated monocarboxylic acids $\left(\mathrm{C}_{9}, \mathrm{C}_{10}, \mathrm{C}_{12}, \mathrm{C}_{14}, \mathrm{C}_{16}, \mathrm{C}_{18}, \mathrm{C}_{20}\right.$, and $\left.\mathrm{C}_{22}\right)$; normal saturated $\alpha$, $\omega$-dicarboxylic acids $\left(\mathrm{C}_{4}, \mathrm{C}_{6}, \mathrm{C}_{8}\right.$, and $\mathrm{C}_{10}$ ); 2,2-dimethyl succinic acid; and benzenecarboxylic acids (benzoic, phthalic, and trimesic acids).

The degradation products were confirmed with a Hewlett-Packard 5985 gas chromatograph-mass spectrometer. The temperature and column conditions were the same as used for GC analyses. Helium was used as carrier gas. The mass spectrometer was operated at an electron 
energy of $70 \mathrm{eV}$, a separator temperature of $300^{\circ} \mathrm{C}$, and an ion source temperature of $200^{\circ} \mathrm{C}$.

\section{CHN Analyses}

Organic carbon in sediment samples and elemental analyses of lipids, humic acid, and kerogen were determined with a Yanagimoto $\mathrm{CHN}$ analyzer (Type MT-2).

\section{Isotopic Measurements}

$\delta^{13} \mathrm{C}$ values were obtained using a Varian Mat 250 isotope mass spectrometer. PDB was used as the standard.

\section{RESULTS AND DISCUSSION}

The lipid contents of Cores 582-1 and 582B-3 are higher than those of deeper samples, whereas the humic acid and kerogen contents of the same cores are slightly low compared to those of deeper sediments (Table 1; Fig. 1). In the cores deeper than $130 \mathrm{~m}$ sub-bottom, the amounts of lipids, humic acid, and kerogen are practically constant: 2.8 to $4.1 \%$ for lipids, 12 to $14 \%$ for humic acids, and 42 to $50 \%$ for kerogens. Some of the total organic matter (36-49\%) was not recovered; it probably consists of fulvic acids and low molecular weight compounds.

The $\mathrm{H} / \mathrm{C}$ and $\mathrm{O} / \mathrm{C}$ ratios for kerogens are lower than those for the humic acids (Table 2; Fig. 2). This distinction may arise from the different methods of separation of humic acid and of kerogen from the sediment sample; that is, humic acid is not treated with mineral acids, whereas kerogen is treated with $6 \mathrm{~N} \mathrm{HCl}$ for $10 \mathrm{hr}$. to diminish inorganic materials. For example, upon hydrolysis of kerogen from Lake Haruna sediment with $6 \mathrm{~N}$ $\mathrm{HCl}$ (Machihara and Ishiwatari, 1980), the ratios of $\mathrm{H} /$ $\mathrm{C}$ and $\mathrm{O} / \mathrm{C}$ decreased substantially: 1.17 to 0.81 and 0.44 to 0.38 , respectively. Although a similar change may have occurred for the kerogens in this experiment, we have no data to ascertain this point, because the ash content of the kerogen is too high (60-70 wt.\%) to obtain accurate evaluations of the hydrogen and oxygen contents.

$\delta^{13} \mathrm{C}$ values of the three fractions change almost in parallel with depth except for a slight low value of the Core 582-1 lipids (Fig. 3), indicating a common source for each. The $\delta^{13} \mathrm{C}$ for each organic fraction of the sample from Core $582 \mathrm{~B}-68$ is relatively high, suggesting that this sample has more organic matter from a marine source

Table 1. Organic carbon, lipids, humic acids, and kerogens in sediments at Site 582.

\begin{tabular}{|c|c|c|c|c|c|}
\hline \multirow{2}{*}{$\begin{array}{l}\text { Hole-Core- } \\
\text { Section }\end{array}$} & \multirow{2}{*}{$\begin{array}{c}\text { Sub- } \\
\text { bottom } \\
\text { depth } \\
\text { (m) }\end{array}$} & \multirow{2}{*}{$\begin{array}{c}\text { Organic } \\
\text { carbon } \\
(\%)\end{array}$} & Lipids & $\begin{array}{l}\text { Humic } \\
\text { acid }\end{array}$ & Kerogen \\
\hline & & & \multicolumn{3}{|c|}{ (mg C/g dry sediment) } \\
\hline $582-1-4$ & 6 & 0.54 & 0.33 & 0.38 & 2.07 \\
\hline 582B-3-1 & 75 & 0.66 & 0.46 & 0.68 & 2.24 \\
\hline 582B-10-2 & 137 & 0.43 & 0.15 & 0.58 & 2.13 \\
\hline $582 \mathrm{~B}-16-1$ & 194 & 0.69 & 0.27 & 1.00 & 2.95 \\
\hline 582B-22-1 & 252 & 0.65 & 0.18 & 0.85 & 2.94 \\
\hline 582B-30-6 & 336 & 0.55 & 0.24 & & 2.79 \\
\hline $582 \mathrm{~B}-40-1$ & 423 & 0.52 & 0.15 & 0.81 & 2.37 \\
\hline $582 \mathrm{~B}-50-2$ & 520 & 0.46 & 0.19 & 0.66 & 2.03 \\
\hline 582B-58-2 & 598 & 0.26 & 0.076 & & 1.09 \\
\hline 582B-68-2 & 694 & 0.35 & 0.14 & 0.44 & 1.45 \\
\hline
\end{tabular}

Note: Blanks indicate no measurement made.

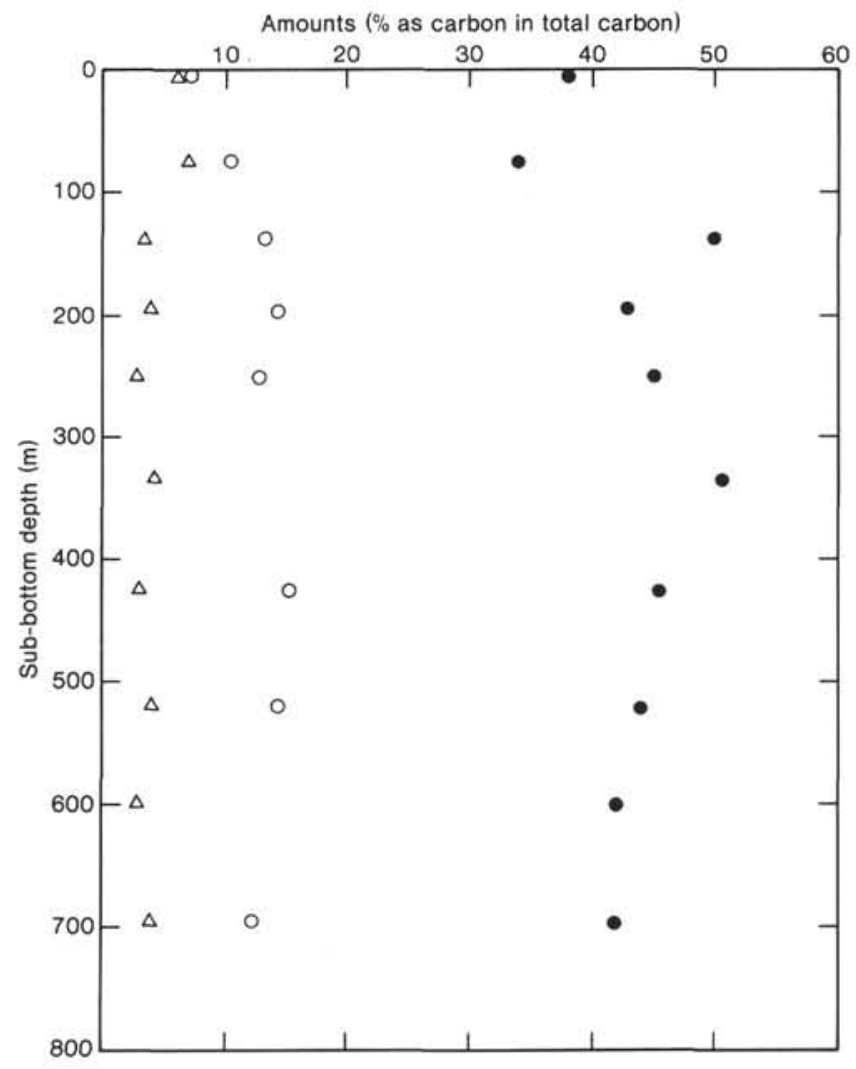

Figure 1. The relation of amounts of lipids (triangles), humic acids (open circles), and kerogens (solid circles) in Site 582 sediments to sub-bottom depth.

than do the other four sediment samples (Degens, 1969). This pattern conforms with sedimentologic, biostratigraphic, and physical properties observations that identify Core 582B-54 as the border between Nankai Trough turbidites above and Shikoku Basin sediments below (site chapter, Site 582, this volume).

Oxidative degradation products obtained from the three fractions are normal $\alpha, \omega$-dicarboxylic acids, benzenecarboxylic acids, normal monocarboxylic acids, and 2,2-dimethyl succinic acid (Table 3 ). These products are commonly observed in oxidation studies of organic matter (lipids, humic acid, and kerogen) in lacustrine sediments (Machihara and Ishiwatari, 1981; Machihara, 1981). For Leg 87 samples, normal $\alpha, \omega$-dicarboxylic acids of the lipids have peaks at $\mathrm{C}_{4}, \mathrm{C}_{6}$, and $\mathrm{C}_{9}$ (Core 582-1, Fig. 4A) or $\mathrm{C}_{6}$ and $\mathrm{C}_{9}$ (Cores 582B-10, 582B-22, and $582 \mathrm{~B}-50$ ), whereas those of the humic acids and kerogen show a maximum peak at $\mathrm{C}_{4}$ (Figs. $4 \mathrm{~B} ; 4 \mathrm{C}$ ). The distribution pattern of the benzenecarboxylic acids are almost the same among the three fractions.

A large portion of the $\alpha, \omega$-dicarboxylic acids of the lipids may have been derived from unsaturated fatty acids or their alteration materials (Ishiwatari and Machihara, 1983). We have observed that lipids extracted from algae (bluegreen and green algae and diatoms) generate $\mathrm{C}_{4}{ }^{-}$ $\mathrm{C}_{12} \alpha$, $\omega$-dicarboxylic acids (with a maximum peak at $\mathrm{C}_{8}$ or $\mathrm{C}_{9}$ ) by their $\mathrm{KMnO}_{4}$ oxidation (Ishiwatari and Machihara, 1982). We have also obtained large quantities of $\mathrm{C}_{4}-\mathrm{C}_{9} \alpha, \omega$-dicarboxylic acids with a maximum peak at 
Table 2. Elementary composition and ${ }^{13} \mathrm{C}$ values of lipids, humic acids, and kerogens.

\begin{tabular}{|c|c|c|c|c|c|c|c|c|c|c|}
\hline \multirow[b]{2}{*}{ Fraction } & \multirow{2}{*}{$\begin{array}{l}\text { Hole-Core- } \\
\text { Section }\end{array}$} & \multicolumn{4}{|c|}{ Elemental analyses ${ }^{\mathrm{a}}(\%)$} & \multirow{2}{*}{$\begin{array}{l}\text { Ash } \\
(\%)\end{array}$} & \multicolumn{3}{|c|}{ Atomic ratios } & \multirow{2}{*}{$\begin{array}{c}\delta^{13} \mathrm{C} \\
\text { (\%o vs. PDB) }\end{array}$} \\
\hline & & C & $\mathrm{H}$ & $\mathrm{N}$ & $\mathrm{O}^{\mathrm{b}}$ & & $\mathrm{H} / \mathrm{C}$ & $\mathrm{N} / \mathrm{C}$ & $\mathrm{O} / \mathrm{C}$ & \\
\hline \multirow[t]{10}{*}{ Lipids } & $582-1-4$ & 75.6 & 9.66 & 1.51 & 13.28 & & 1.54 & 0.017 & 0.13 & -25.8 \\
\hline & $582 \mathrm{~B}-3-1$ & 80.5 & 11.3 & 0.97 & 7.18 & & 1.69 & 0.010 & 0.07 & \\
\hline & $582 \mathrm{~B}-10-2$ & 82.0 & 11.2 & 1.50 & 5.28 & & 1.64 & 0.016 & 0.05 & -25.7 \\
\hline & $582 \mathrm{~B}-16-1$ & 82.3 & 11.3 & 0.90 & 5.51 & & 1.65 & 0.009 & 0.05 & \\
\hline & $582 \mathrm{~B}-22-1$ & 77.9 & 10.8 & 1.49 & 9.82 & & 1.67 & 0.016 & 0.09 & -25.7 \\
\hline & $582 \mathrm{~B}-30-6$ & 81.1 & 11.4 & 1.05 & 6.51 & & 1.68 & 0.011 & 0.06 & \\
\hline & $582 \mathrm{~B}-40-1$ & 78.8 & 11.0 & 1.47 & 8.71 & & 1.68 & 0.016 & 0.08 & \\
\hline & $582 \mathrm{~B}-50-2$ & 79.8 & 11.0 & 1.22 & 7.99 & & 1.65 & 0.013 & 0.08 & -25.8 \\
\hline & $582 \mathrm{~B}-58-2$ & 79.8 & 11.0 & 1.54 & 7.72 & & 1.65 & 0.017 & 0.07 & \\
\hline & $582 \mathrm{~B}-68-2$ & 80.4 & 10.8 & 1.58 & 7.20 & & 1.62 & 0.017 & 0.07 & -25.2 \\
\hline \multirow[t]{10}{*}{ Humic acids } & $582-1-4$ & 56.2 & 4.90 & 3.50 & 35.4 & 4.60 & 1.05 & 0.053 & 0.47 & -22.2 \\
\hline & $582 \mathrm{~B}-3-1$ & 55.2 & 4.89 & 3.91 & 36.0 & 11.0 & 1.06 & 0.061 & 0.49 & \\
\hline & $582 \mathrm{~B}-10-2$ & 55.7 & 5.53 & 3.44 & 35.3 & 44.8 & 1.19 & 0.053 & 0.48 & -23.4 \\
\hline & 582B-16-1 & 55.4 & 5.52 & 3.32 & 35.6 & 44.6 & 1.20 & 0.051 & 0.48 & \\
\hline & $582 \mathrm{~B}-22-1$ & 56.3 & 6.00 & 3.39 & 34.3 & 39.8 & 1.28 & 0.052 & 0.46 & -23.3 \\
\hline & $582 \mathrm{~B}-30-6$ & 55.4 & 5.27 & 3.77 & 35.6 & 4.90 & 1.14 & 0.058 & 0.48 & \\
\hline & $582 \mathrm{~B}-40-1$ & 57.1 & 5.06 & 2.99 & 34.9 & 24.1 & 1.06 & 0.045 & 0.46 & \\
\hline & $582 \mathrm{~B}-50-2$ & 58.5 & 4.94 & 2.79 & 33.8 & 27.6 & 1.01 & 0.041 & 0.43 & -23.1 \\
\hline & 582B-58-2 & 61.9 & 5.03 & 3.49 & 29.6 & 1.4 & 0.97 & 0.048 & 0.36 & \\
\hline & 582B-68-2 & 60.8 & 5.69 & 4.22 & 29.3 & 2.8 & 1.12 & 0.059 & 0.36 & -20.7 \\
\hline \multirow[t]{10}{*}{ Kerogens } & $582-1-4$ & 71.2 & 3.91 & 2.14 & 22.8 & 6.47 & 0.66 & 0.026 & 0.24 & -23.4 \\
\hline & 582B-3-1 & 69.6 & 4.17 & 1.95 & 24.3 & 7.97 & 0.72 & 0.024 & 0.26 & \\
\hline & $582 \mathrm{~B}-10-2$ & 70.5 & 4.20 & 1.74 & 23.5 & 9.00 & 0.71 & 0.021 & 0.25 & -24.3 \\
\hline & $582 \mathrm{~B}-16-1$ & 68.9 & 4.63 & 1.86 & 24.6 & 7.43 & 0.81 & 0.023 & 0.27 & \\
\hline & $582 \mathrm{~B}-22-1$ & 69.9 & 4.33 & 1.80 & 24.0 & 8.12 & 0.74 & 0.022 & 0.26 & -24.6 \\
\hline & $582 \mathrm{~B}-30-6$ & 69.2 & 4.36 & 1.92 & 24.6 & 6.93 & 0.76 & 0.024 & 0.27 & \\
\hline & $582 \mathrm{~B}-40-1$ & 71.6 & 4.62 & 2.08 & 21.7 & 5.60 & 0.77 & 0.025 & 0.23 & \\
\hline & $582 \mathrm{~B}-50-2$ & 71.6 & 4.57 & 1.91 & 21.9 & 6.50 & 0.76 & 0.023 & 0.23 & -24.3 \\
\hline & $582 \mathrm{~B}-58-2$ & 70.4 & 4.02 & 1.88 & 23.6 & 15.1 & 0.68 & 0.023 & 0.25 & \\
\hline & $582 \mathrm{~B}-68-2$ & 65.4 & 4.19 & 2.16 & 28.2 & 20.5 & 0.77 & 0.028 & 0.32 & -22.9 \\
\hline
\end{tabular}

Note: Blank indicates not measured.

a Ash-free basis.

$\mathrm{b}$ By difference.

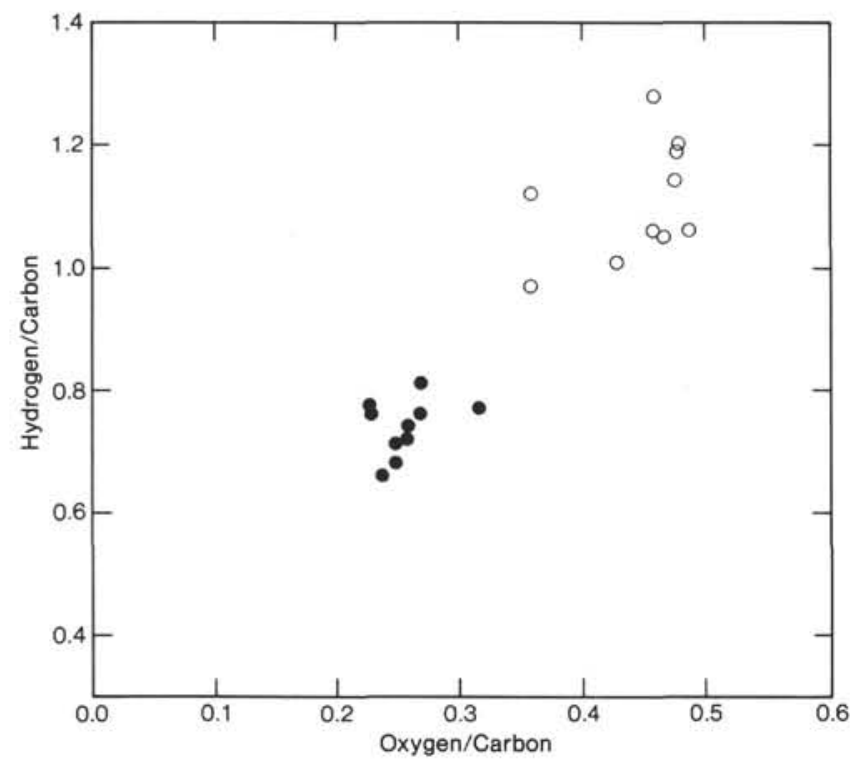

Figure 2. The oxygen/carbon versus hydrogen/carbon atomic ratios for the humic acids and kerogens. Symbols as in Figure 1.

$\mathrm{C}_{8}$ or $\mathrm{C}_{9}$ by oxidation of authentic standards such as $\Delta^{9}$ $\mathrm{C}_{16: 1}, \Delta^{9}-\mathrm{C}_{18: 1}, \Delta^{9,12}-\mathrm{C}_{18: 2}$, and $\Delta^{9,12,15}-\mathrm{C}_{18: 3}$ (Machihara and Ishiwatari, 1983).

Interestingly, the distribution pattern of $\alpha, \omega$-dicarboxylic acids obtained from the kerogens (and humic acids) in these marine sediments is different from those in

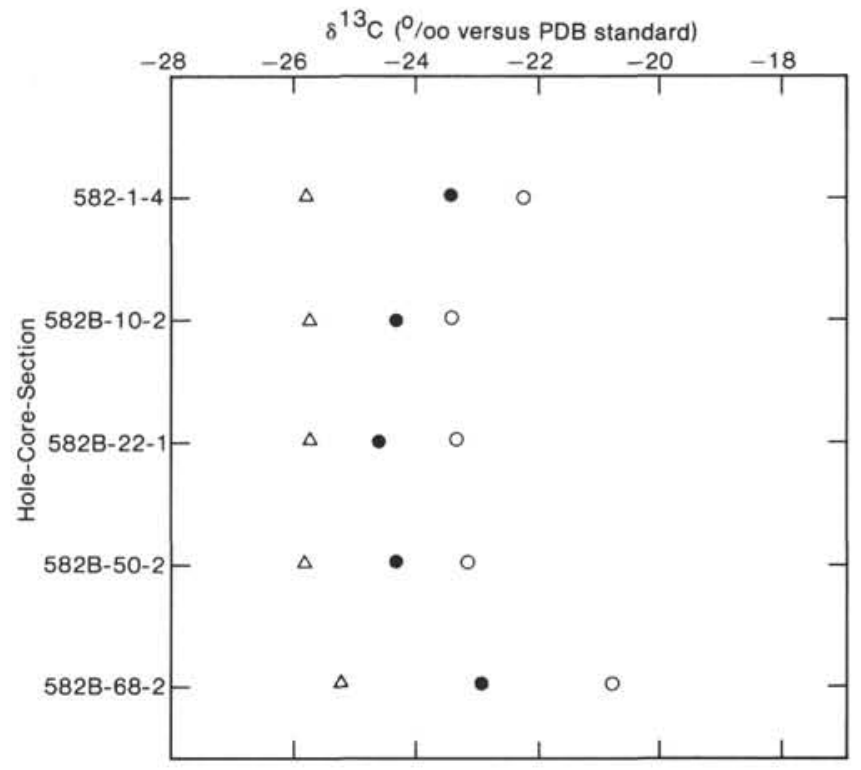

Figure 3. $\delta^{13} \mathrm{C}$ values in each organic fraction for samples from Holes 582 and 582B. Symbols as in Figure 1.

lacustrine sediments (Machihara and Ishiwatari, 1980, $1981)$. In other words, $\alpha, \omega$-dicarboxylic acids of the marine sediments have a maximum peak at $\mathrm{C}_{4}$ and decrease with increasing carbon numbers, whereas those of the lacustrine sediments show a maximum peak at $\mathrm{C}_{8}$. This contrast may be due to the difference of precursor mate- 
Table 3. Yield of organic compounds produced by oxidation of each fraction (expressed as $\mathrm{mg} / \mathrm{g}$ organic carbon).

\begin{tabular}{|c|c|c|c|c|}
\hline $\begin{array}{l}\text { Hole-Core- } \\
\text { Section }\end{array}$ & Degradation products & Lipids & $\underset{\text { acid }}{\text { Humic }}$ & Kerogen \\
\hline \multirow[t]{5}{*}{$582-1-4$} & $\mathrm{n}-\mathrm{C}_{8} \sim \mathrm{n}-\mathrm{C}_{26}$ monocarboxylic acids & 5.39 & 3.95 & 0.59 \\
\hline & n- $C_{4} \sim n-C_{14} \alpha, \omega$-dicarboxylic acids & 16.5 & 34.4 & 10.5 \\
\hline & Benzenecarboxylic acids & 16.5 & 6.2 & 5.47 \\
\hline & 2,2-dimethyl succinic acid & 1.83 & 1.63 & 0.54 \\
\hline & Total & 40.2 & 46.2 & 17.1 \\
\hline \multirow[t]{5}{*}{$582 \mathrm{~B}-10-2$} & $\mathrm{n}-\mathrm{C}_{8}-\mathrm{n}-\mathrm{C}_{26}$ monocarboxylic acids & 7.46 & 1.58 & 2.02 \\
\hline & n- $C_{4} \sim n-C_{14} \alpha, \omega$-dicarboxylic acids & 22.4 & 24.1 & 15.8 \\
\hline & Benzenecarboxylic acids & 7.0 & 5.94 & 6.03 \\
\hline & 2,2-dimethyl succinic acid & 1.36 & 1.38 & 0.87 \\
\hline & Total & 38.2 & 33.0 & 24.7 \\
\hline \multirow[t]{5}{*}{$582 \mathrm{~B}-22-1$} & $\mathrm{n}-\mathrm{C}_{8} \sim \mathrm{n}-\mathrm{C}_{26}$ monocarboxylic acids & 9.82 & 1.29 & 1.89 \\
\hline & n- $C_{4} \sim n-C_{14} \alpha, \omega$-dicarboxylic acids & 40.4 & 24.3 & 16.9 \\
\hline & Benzenecarboxylic acids & 7.6 & 3.41 & 5.62 \\
\hline & 2,2-dimethyl succinic acid & 2.40 & 1.40 & 0.94 \\
\hline & Total & 60.2 & 30.4 & 25.4 \\
\hline \multirow[t]{5}{*}{$582 \mathrm{~B}-50-2$} & $\mathrm{n}-\mathrm{C}_{8}-\mathrm{n}-\mathrm{C}_{26}$ monocarboxylic acids & 8.96 & 2.06 & 1.70 \\
\hline & n- $C_{4} \sim n-C_{14} \alpha, \omega$-dicarboxylic acids & 31.7 & 22.4 & 14.2 \\
\hline & Benzenecarboxylic acids & 6.2 & 5.95 & 10.0 \\
\hline & 2,2-dimethyl succinic acid & 2.04 & 1.62 & 0.84 \\
\hline & Total & 48.9 & 32.0 & 26.7 \\
\hline
\end{tabular}

rials (i.e., unsaturated fatty acids). The composition of unsaturated fatty acids is remarkably different between fresh-water and seawater algae (Pohl et al., 1968; Jamieson and Reid, 1972). The former consist mainly of $\Delta^{7}$ or $\Delta^{9}-\mathrm{C}_{16: 1}, \Delta^{9}-\mathrm{C}_{18: 1}, \Delta^{9,12}-\mathrm{C}_{18: 2}$, and $\Delta^{9,12,15}-\mathrm{C}_{18: 3}$, whereas the latter, in addition to those unsaturated fatty acids, contain polyunsaturated fatty acids ( $\geq 4$ double bonds) such as $\Delta^{6,9,12,15}-\mathrm{C}_{18: 4}, \Delta^{5,8,11,14}-\mathrm{C}_{20: 4}, \Delta^{8,11,14,17}-\mathrm{C}_{20: 4}$, $\Delta^{5,8,11,14,17}-C_{20: 5}, \Delta^{7,10,13,16,19}-C_{22: 5}$, and $\Delta^{4,7,10,13,16,19}-C_{22: 6}$. Therefore, if we assume that polyunsaturated fatty acids ( $\geq 4$ double bonds) have been incorporated in the kerogen and humic acids, then $\mathrm{C}_{4}-\mathrm{C}_{7} \alpha$, $\omega$-dicarboxylic acids should be produced from the oxidation of kerogen and humic acids; e.g., $C_{4}, C_{5}, C_{6}$, and $C_{7}$ from $\Delta^{4,7,10,13,16,19}$ $\mathrm{C}_{22: 6}, \Delta^{5,8,11,14}-\mathrm{C}_{20: 4}, \Delta^{6,9,12,15}-\mathrm{C}_{18: 4}$, and $\Delta^{7,10,13,16,19}-\mathrm{C}_{22: 5}$, respectively.

The distribution patterns of $\alpha, \omega$-dicarboxylic acids between lipids and kerogen (or humic acid) differ from each other. In the case of the oxidation study of three organic fractions (lipids, humic acid, and kerogen) in a lacustrine sediment, such differences were not observed (Ishiwatari and Machihara, 1983). This contrast may be interpreted in terms of the reactivity of unsaturated fatty acids with kerogen (or humic acid). Polyunsaturated fatty acids ( $\geq 4$ double bonds) may have reacted more easily with kerogen (humic acid) than unsaturated fatty acids ( $\leq 3$ double bonds) and were incorporated in their matrices. On this assumption, lipids become richer in $C_{16: 1}$ and $C_{18: 1,2,3}$ unsaturated fatty acids (or their alteration products), compared to kerogen (or humic acid). Thus, upon oxidation, lipids would generate $\alpha, \omega$-dicarboxylic acids with a maximum at $\mathrm{C}_{8}$ or $\mathrm{C}_{9}$. At present, however, this interpretation is speculative. Further study is needed to elucidate the high reactivity of polyunsaturated fatty acids ( $\geq 4$ double bonds) with kerogen and their incorporation into kerogen matrix.

In all of the oxidation products of the three fractions, 2,2-dimethyl succinic acid was detected. A precursor of this acid is probably carotenoid pigments (e.g., $\beta$-caro- tene; Machihara and Ishiwatari, 1983). Although small amounts of 2,2-dimethyl glutaric acid, which is also obtained by oxidation of $\beta$-carotene, were detected, its yield was not measured in this experiment. Yield of 2,2-dimethyl succinic and glutaric acids produced from the oxidation of $\beta$-carotene was 5.5 wt. $\%$ (Machihara and Ishiwatari, 1983). Therefore, the content of $\beta$-carotene in the lipids, humic acid, and kerogen in the sediments can be estimated approximately, assuming that 2,2-dimethyl succinic acid was derived from $\beta$-carotene (or related compounds). The amount is calculated as 2.5 to $4.4 \%$ for the lipids, 2.5 to $2.9 \%$ for the humic acids, and 0.9 to $1.6 \%$ for the kerogens.

The amounts of polymethylene chains in the three organic fractions in the sediments were calculated $\mathrm{CTa}$ ble 4) using the quantified amounts of the three fractions (Table 1) and the yields of aliphatic acids produced by the oxidation of each fraction (Table 3 ). In this calculation, the yield of aliphatic acids from polymethylene chains by $\mathrm{KMnO}_{4}$ oxidation was assumed to be the same for the three fractions. The order of abundance of these chains in the sediments is kerogen, $52-66 \%$ of total methylene chains; humic acid, 25-33\%; and lipids, 8$16 \%$. The distribution of polymethylene chains among the three fractions is almost unrelated to depth of the sample.

\section{CONCLUSIONS}

1. The amounts of lipids, humic acids, and kerogens in sediment cores $(5.6-694 \mathrm{~m})$ were almost unrelated to depth of the samples. The order of amounts of these types of organic matter in the sediment is kerogens, 34$51 \%$ of total organic carbon; humic acids, 7.1-15.5\%; and lipids, 2.4-7.0\%.

2. $\delta^{13} \mathrm{C}$ values of the three fractions varied almost in parallel with depth. This uniformity indicates a common source for the lipids, humic acid, and kerogen in each sediment sample.

3. Oxidation study of the each fraction showed that the distribution pattern of polymethylene chain lengths differs between the lipids and kerogen (or humic acid). Thus, polyunsaturated fatty acids ( $\geq 4$ double bonds) may play an important role in the formation of polymethylene chain structure in marine kerogen and humic acid.

4. A significant amount of carotenoid pigments may also be responsible for the polymethylene chain structure in kerogen and humic acid.

5. The polymethylene chains in the sediments are dominant in the kerogen fraction. The abundance was calculated to be 52 to $66 \%$ of total methylene chains in the sediments.

\section{ACKNOWLEDGMENTS}

I would like to thank Japan National Oil Corporation (JNOC) for the permission to publish the paper. Thanks are due to Dr. K. Aoyagi and Dr. S. Sato (JNOC) for their continuing encouragement during this work. I am also grateful to Mr. M. Omokawa (JNOC) for the carbon isotope analysis, and Dr. P. Schenk of Dalhousie University for his valuable comments on the manuscript. I wish to thank Dr. Y. Ishiwada (JNOC) for giving me the opportunity to participate in Leg 87. 

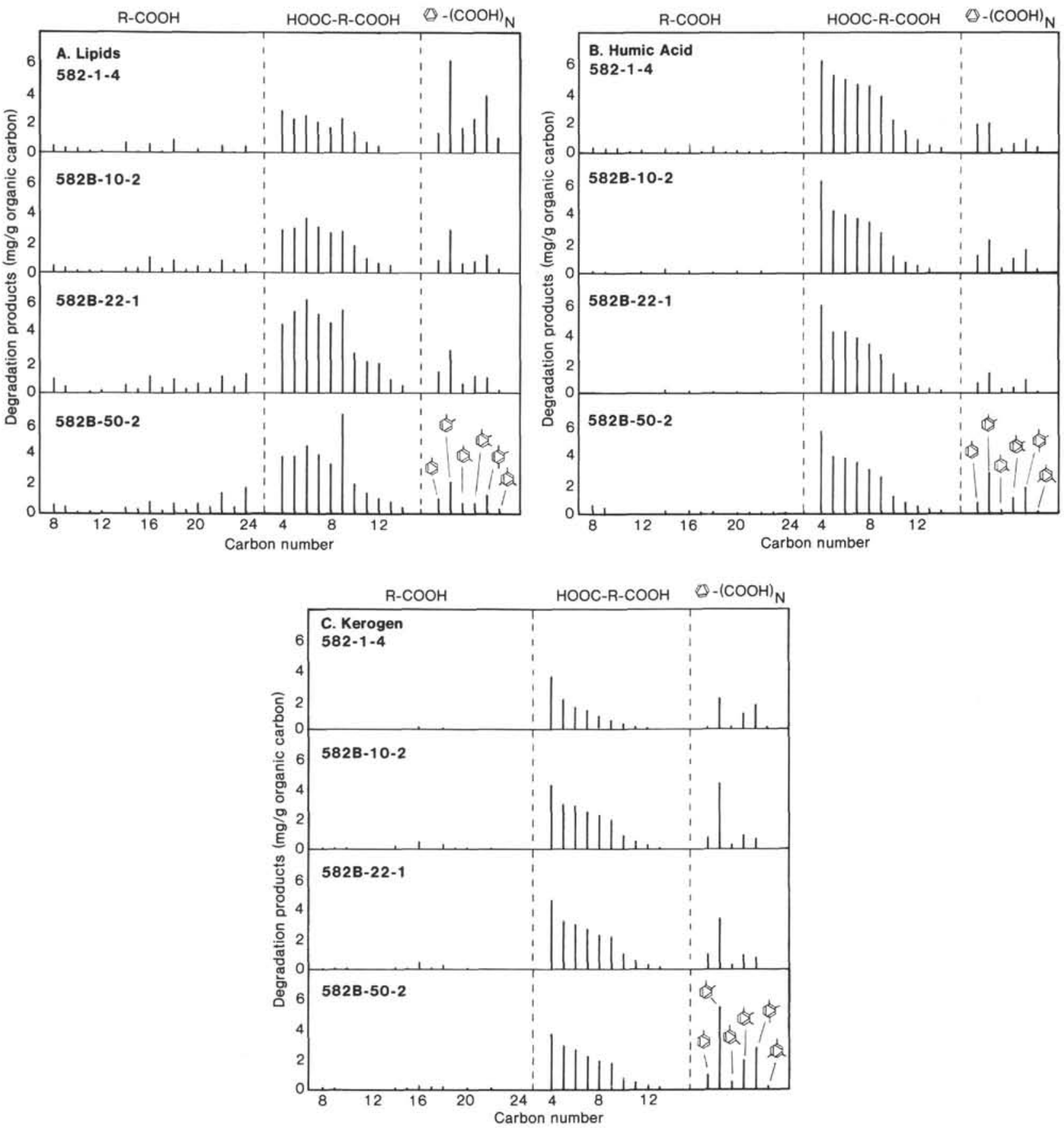

Figure 4. Distributions of aliphatic monocarboxylic and dicarboxylic acids and benzenecarboxylic acids in the oxidation products. A. Lipids; B. Humic acid; C. Kerogen. R-COOH, HOOC-R-COOH, and $\$-(\mathrm{COOH})_{\mathrm{N}}$ indicate aliphatic monocarboxylic acids, aliphatic $\alpha, \omega$-dicarboxylic acids, and benzenecarboxylic acids, respectively.

Table 4. Distribution of polymethylene chains in the sediments.

\begin{tabular}{|c|c|c|c|c|c|c|}
\hline \multirow[b]{2}{*}{$\begin{array}{l}\text { Hole-Core- } \\
\text { Section }\end{array}$} & \multicolumn{3}{|c|}{$\begin{array}{l}\text { Concentration of polymeth- } \\
\text { ylene chains in the sediment } \\
\qquad(\mu \mathrm{g} / \mathrm{g} \mathrm{C})\end{array}$} & \multicolumn{3}{|c|}{ Relative abundance $(\%)$} \\
\hline & Lipids & $\underset{\text { acid }}{\text { Humic }}$ & Kerogen & Lipids & $\begin{array}{c}\text { Humic } \\
\text { acid }\end{array}$ & Kerogen \\
\hline $582-1-4$ & 7.0 & 14.2 & 22.5 & 16 & 33 & 52 \\
\hline $582 \mathrm{~B}-10-2$ & 4.5 & 14.9 & 38.0 & 7.8 & 26 & 66 \\
\hline $582 \mathrm{~B}-22-1$ & 9.0 & 21.8 & 55.3 & 11 & 25 & 64 \\
\hline $582 \mathrm{~B}-50-2$ & 7.7 & 15.6 & 32.3 & 14 & 28 & 58 \\
\hline
\end{tabular}

\section{REFERENCES}

Degens, E. T., 1969. Biogeochemistry of stable carbon isotopes. In Eglinton, G., and Murphy, M. T. J. (Eds.), Organic Geochemistry: New York (Springer-Verlag), pp. 304-329.

Degens, E. T., Reuter, J. H., and Shaw, N. F., 1964. Biochemical compounds in offshore California sediments and seawater. Geochim. Cosmochim. Acta, 28:45-66.

Hunt, J. M., 1979. Petroleum Geochemistry and Geology: San Francisco (W. H. Freeman and Company).

Ishiwatari, R., and Machihara, T., 1982. Algal lipids as a possible contributor to the polymethylene chains in kerogen. Geochem. Cosmochim. Acta, 46:1459-1464. 
1983. Early stage incorporation of biolipids into kerogen in a lacustrine sediment: evidence from alkaline potassium permanganate oxidation of sedimentary lipids and humic matter. Org. Geochem., 4:179-184.

Jamieson, G. R., and Reid, E. H., 1972. The component fatty acids of some marine algal lipids. Phytochemistry, 11:1423-1432.

Kagami, H., Karig, D. E., and Shipboard Scientific Party, 1983. Leg 87 drills off Honshu and southwest Japan. Geotimes, 28 (1):15-18

Machihara, T., 1981. Geochemical studies of organic matter (kerogen) in recent sediments [Ph.D. thesis]. Tokyo Metropolitan University, Tokyo.

Machihara, T., and Ishiwatari, R., 1980. Characterization of young kerogen in a lacustrine sediment by alkaline permanganate oxidation. Geochem. J., 14:279-288.

1981. Characteristics of insoluble organic matter in lake sediments as revealed by alkaline potassium permanganate oxidation. Verh. Int. Ver. Limnol., 21:244-247.

1983. Evaluation of alkaline permanganate oxidation method for the characterization of young kerogen. Org. Geochem., 5: 111-119.

Philp, R. P., Calvin, M., Brown, S., and Yang, E., 1978. Organic geochemical studies on kerogen precursors in recently deposited algal mats and oozes. Chem. Geol., 22:207-231.

Philp, R. P., and Yang, E., 1977. Alkaline potassium permanganate degradation of insoluble organic residues (kerogen) isolated from recently-deposited algal mats. Energy Sources, 3:149-161.
Pohl, P., Wagner, H., and Passig, T., 1968. Inhaltsstoffe von Algen-II Über die unterschiedliche fettsaurzusammensetzung von salz- und süsswasseralgen. Phytochemistry, 7:1565-1572.

Sato, S., 1980. Diagenetic alteration of organic matter in Leg 57 sediments, Deep Sea Drilling Project. In Scientific Party, Init. Repts. DSDP, 56, 57, Pt. 2: Washington (U.S. Govt. Printing Office), 1305-1312.

Sklarew, D. S., 1979. Analysis and simulated diagenesis of kerogen in a Recent bottom mud from Mono Lake, California: a comparison with selected ancient kerogens. Geochim. Cosmochim. Acta, 43: 1949-1958.

Stuermer, D. H., Peters, K. E., and Kaplan, I. R., 1978. Source indicators of humic substances and proto-kerogen. Stable isotope ratios, elemental compositions and electron spin resonance spectra. Geochim. Cosmochim. Acta, 42:989-997.

Tissot, B. P., and Welte, D. H., 1978. Petroleum Formation and Occurrence: Berlin, New York (Springer-Verlag).

Welte, D. H., 1972. Petroleum exploration and organic geochemistry. J. Geochem. Explor., 1:117-136.

Date of Initial Receipt: 13 January 1984

Date of Acceptance: 13 July 1984 